\title{
Neurotrophin-4/5 Is a Mammalian-specific Survival Factor for Distinct Populations of Sensory Neurons
}

\author{
Alun M. Davies, ${ }^{1}$ Antony Horton, ${ }^{1}$ Louis E. Burton, ${ }^{2}$ Charles Schmelzer, ${ }^{2}$ Richard Vandlen, ${ }^{2}$ and Arnon \\ Rosenthal' \\ ${ }^{1}$ School of Biological and Medical Sciences, St. Andrews University, St. Andrews, Fife KY16 9AJ, Scotland, and \\ 2Department of Neuroscience, Genentech, Inc., South San Francisco, California 94080
}

\begin{abstract}
We have studied the effect of human recombinant neurotrophin-4/5 (NT-4/5) on the survival of developing PNS neurons from embryonic mice and chickens. NT-4/5 transiently supported mouse NGF-dependent trigeminal and jugular neurons at early stages of target field innervation and mouse brain-derived neurotrophic factor (BDNF)-dependent nodose neurons during the phase of naturally occurring cell death. NT-4/5 was as potent as BDNF in supporting the survival of these neuronal populations. Surprisingly, NT-4/5 was 3 orders of magnitude less potent than BDNF as a survival factor for early chick dorsomedial trigeminal sensory neurons and did not support the survival of chick BDNF-dependent trigeminal mesencephalic or ventrolateral trigeminal sensory neurons at any of the developmental stages tested. Thus, NT-4/5 is a survival factor for certain embryonic mouse cranial sensory neurons. It is the first species-specific neurotrophin to be identified and it can discriminate at high concentrations between different BDNF-responsive chick neurons.
\end{abstract}

[Key words: neurotrophin-4/5, brain-derived neurotrophic factor, sensory neurons, survival factor, cranlal neurons, cell death]

The neurotrophins comprise a family of structurally related, secreted, $13 \mathrm{kDa}$ homodimeric proteins. In mammals, this family includes NGF (Levi-Montalcini and Angeletti, 1968), brainderived neurotrophic factor (BDNF) (Barde et al., 1982; Leibrock et al., 1989), neurotrophin-3 (NT-3) (Ernfors et al., 1990; Hohn et al., 1990; Jones and Reichardt, 1990; Maisonpierre et al., 1990; Rosenthal et al., 1990), and NT-4/5 (Berkemeier et al., 1991; Ip et al., 1992). NGF, BDNF, and NT-3 are potent survival factors for distinct sets of embryonic neurons from the CNS and PNS in vitro (Chun and Patterson, 1977; Johnson et al., 1986; Davies, 1987; Hatanaka et al., 1988; Hohn et al., 1990; Hyman et al., 1991; Henderson et al., 1993) and in vivo (Levi-Montalcini and Angeletti, 1968; Johnson et al., 1982; Kalcheim et al., 1987; Hofer and Barde, 1988; Oppenheim et al., 1992; Sendtner et al., 1992; Yan et al., 1992), mitogens for neuronal progenitors (Cattaneo and McKay, 1990; Kalcheim et

Received Mar. 2, 1993; revised May 14, 1993; accepted May 24, 1993.

We thank Kerrie Andow and Wayne Anstine for help in preparing the manuscript. This work was supported in part by a grant from Action Research.

Correspondence should be addressed to Dr. Arnon Rosenthal, Department of Neuroscience, Genentech, Inc., 460 Point San Brouno Boulevard, South San Francisco, CA 94080.

Copyright (C) 1993 Society for Neuroscience $0270-6474 / 93 / 134961-07 \$ 05.00 / 0$ al., 1992), and differentiation accelerating factors for immature neurons (Cattaneo and McKay, 1990; Sieber, 1991; Wright et al., 1992). These three neurotrophins are structurally and functionally conserved in evolution. Thus, NGF, BDNF, and NT-3 from frog and mammals share $90-95 \%$ of their primary structure (Hallbook et al., 1991) and neurons from avians, reptiles, amphibians and rodents respond equally well to the mammalian factors (Thoenen and Barde, 1980; Levi-Montalcini and Aloe, 1985; Barde et al., 1987; Hohn et al., 1990; Maisonpierre et al., 1990; Rosenthal et al., 1990; Buchman et al., 1993). NT-4/5 (Berkemeier et al., 1991; Ip et al., 1992) is the most recently identified member of the neurotrophin family and its biological activity and species specificity have not yet been determined quantitatively. We determined the ability of recombinant NT$4 / 5$ to promote the survival of cranial neurons from chick and mouse at different embryonic stages.

Cranial sensory neurons have been useful in studying the specificity of neurotrophins (Davies, 1987). In contrast to the functional heterogeneity of neurons in dorsal root ganglia (DRG), cranial sensory neurons are segregated into populations that deal with different kinds of sensation. Perhaps as a consequence of this functional segregation, different populations of cranial sensory neurons have distinct neurotrophin requirements when cultured during the period of naturally occurring cell death. In the chick embryo, the small-diameter cutaneous sensory neurons of the jugular ganglion and the dorsomedial part of the trigeminal ganglion (DMTG) are supported by NGF (Davies and Lindsay, 1985) but show little response to BDNF (Davies et al., 1986b) or NT-3 (Hohn et al., 1990). The large-diameter cutancous scnsory ncurons of the ventrolateral part of the trigeminal ganglion (VLTG) are supported by BDNF (Davies et al., 1986b) but show little response to NGF (Davies and Lumsden, 1983) or NT-3 (Hohn et al., 1990). The proprioceptive neurons of the trigeminal mesencephalic nucleus (TMN) are supported by BDNF or NT-3 (Davies et al., 1986a; Hohn et al., 1990) but are unresponsive to NGF (Davies et al., 1987). The enteroceptive neurons of the nodose ganglion contain subpopulations of neurons that are supported by either BDNF or NT-3 (Lindsay et al., 1985; Davies et al., 1986b; Hohn et al., 1990) but are unresponsive to NGF (Lindsay and Rohrer, 1985). Cranial sympathetic and parasympathetic neurons also have distinct neurotrophin requirements. Superior cervical sympathetic ganglion (SCG) neurons are supported by NGF and NT-3 (Chun and Patterson, 1977; Greene, 1977; Rosenthal et al., 1990) and the parasympathetic neurons of the ciliary ganglion are supported by ciliary neurotrophic factor (CNTF) but not by NGF, BDNF, or NT-3 (Barbin et al., 1984; Davies et al., 1986b; Hohn et al., 
1990). In addition, recent studies have shown that the survival of NGF-dependent cranial sensory neurons is transiently supported by BDNF and NT-3 during the early stages of target field innervation before the onset of naturally occurring neuronal death (Buchman and Davies, 1993; A. M. Buj-Bello, L. Pinon, and $\mathrm{A}$. M. Davies, unpublished observations). These neurons therefore are also useful for studying the changes in requirements for neurotrophic factors during development.

Comparing NT-4/5 to other neurotrophins, we show that NT$4 / 5$ and BDNF are survival factors for the same populations of mouse cranial neurons and that they are equipotent. In addition, we demonstrate that NT-4/5 is much less effective than BDNF as a survival factor for chick neurons and that some populations of BDNF-dependent chick neurons respond to high concentrations of NT-4/5 while others do not.

\section{Materials and Methods}

Dissection of embryonic tissues. Mouse embryos were obtained from overnight matings of $\mathrm{CD} 1$ mice. Pregnant females were killed by cervical dislocation and the precise stage of development of the embryos was determined by the criteria of Theiler (1972). Electrolytically sharpened tungsten needles were used to dissect trigeminal, jugular, nodose, and superior cervical sympathetic ganglia (SCG) from embryonic day 10 (E10)-E18 embryos.

Chick embryos at different stages of development were obtained by incubating white Leghorn chick eggs at $38^{\circ} \mathrm{C}$ in a forced-draft incubator for the required time. The trigeminal, jugular, nodose, SCG, and ciliary ganglia were dissected from chick embryos at F.10 and also at F.6 in the case of the trigeminal ganglion (Davies, 1989). The trigeminal ganglion was subdissected into its neural crest-derived dorsomedial pole (DMTG) and placode-derived ventrolateral pole (VLTG). The median component of the trigeminal mesencephalic nucleus (TMN) was dissected from E10 embryos (Davies, 1986).

Neuronal cultures. Embryonic mouse ganglia were incubated for 5 min at $37^{\circ} \mathrm{C}$ with $0.05 \%$ trypsin (Worthington) in calcium/magnesiumfree Hanks balanced salt solution (HBSS). Embryonic chick ganglia were incubated for $10-15 \mathrm{~min}$ at $37^{\circ} \mathrm{C}$ with $0.1 \%$ trypsin in HBSS. After removal of the trypsin solution, the ganglia were washed twice with 10 ml of Ham's F12 medium containing $10 \%$ heat-inactivated horse serum (HIHS) and were gently triturated with a fire-polished, siliconized Pasteur pipette to give a single-cell suspension. Mouse cells and E6 chick embryo cells were directly plated at a density of $200-400$ neurons per dish in $35 \mathrm{~mm}$ plastic tissue culture dishes (Nunc) that had been precoated with polyornithine $(0.5 \mathrm{mg} / \mathrm{ml}$, overnight $)$ and laminin $(20 \mu \mathrm{l} /$ $\mathrm{ml}$ for $4 \mathrm{hr}$ ). Non-neuronal cells were removed from $\mathrm{E} 10$ chicken dissociated cell suspensions by differential sedimentation (Davies, 1986). The resulting neuronal suspensions were plated in $35 \mathrm{~mm}$ polyornithine/ laminin-coated dishes at a density of 400-600 neurons per dish. Embryonic chick neurons were grown in F14 plus $10 \%$ HIHS. Examination of these cultures by phase contrast microscopy $48 \mathrm{hr}$ after plating revealed less than $5 \%$ non-neuronal cells. Embryonic mouse neurons were grown in a defined medium consisting of Ham's F14 supplemented with $2 \mathrm{~mm}$ glutamine, $0.35 \%$ bovine serum albumin (Pathocyte- 4 , ICN), 60 $\mathrm{ng} / \mathrm{ml}$ progesterone, $16 \mu \mathrm{g} / \mathrm{ml}$ putrescine, $400 \mathrm{ng} / \mathrm{ml} \mathrm{L}$-thyroxine, $38 \mathrm{ng} /$ $\mathrm{ml}$ sodium selenite, $340 \mathrm{ng} / \mathrm{ml}$ tri-iodothyronine, $60 \mathrm{mg} / \mathrm{ml}$ penicillin, and $100 \mathrm{mg} / \mathrm{ml}$ streptomycin. This medium was not conducive to the growth of non-neuronal cells, with the result that over $90 \%$ of the cells in these cultures were neurons after $48 \mathrm{hr}$ of incubation.

Six to twelve hours after plating, the number of attached neurons within a $12 \times 12 \mathrm{~mm}$ square in the center of each dish was counted; the mean of these counts was taken as the initial number of neurons in the experiment. After $48 \mathrm{hr}$ of incubation, the percentage neuronal survival in the absence or presence of different neurotrophins was estimated by counting the number of remaining neurons in the same 12 $\times 12 \mathrm{~mm}$ area in each dish and expressing the results as a percentage of the initial number of attached neurons. In each experiment, triplicate cultures were set up for all conditions.

Recombinant human NT-4/5 was produced in either $\mathrm{CHO}$ cells or Escherichia coli cells. The recombinant protein was purified as described previously for NT-3 and for other neurotrophins (Rosenthal et al., 1990, 1991). Neurotrophins were added to the culture medium before plating the neurons.

\section{Results}

$N T-4 / 5$ is a survival factor for specific mouse embryo neurons Low-density, dissociated cultures of trigeminal, jugular, nodose, SCG, and DRG neurons were established from mouse embryos between E10 and E18. These neurons were grown either in medium alone (control cultures) or in medium supplemented with NGF, BDNF, or NT-4/5. Except for nodose and jugular neurons at a very early stage of their development, virtually all neurons died in control cultures by $48 \mathrm{hr}$. Thus, the effects of neurotrophins on neuronal survival could be clearly observed at this time. Furthermore, because the serum-free medium used in these cultures prevented the growth of fibroblasts and glial cells, neuronal survival was not influenced by the release of growth factors from non-neuronal cells. For each experiment the number of neurons that initially attached to the plates was determined 6-9 $\mathrm{hr}$ after plating and the percentage of neurons surviving after $48 \mathrm{hr}$ was calculated. As depicted in Figure 1, similar numbers of trigeminal, jugular, nodose, SCG, and DRG neurons had survived in the presence of BDNF and NT-4/5, whereas the survival response to NGF was markedly different. BDNF and NT-4/5 were both potent survival factors for El 1 trigeminal and jugular neurons but were unable to support the survival of these two neuronal populations at E15. In contrast, NGF did not support the survival of E1 1 trigeminal and jugular neurons but was a potent survival factor for these neurons from E13 onward. The majority of nodose neurons were supported by BDNF and NT-4/5 throughout their development from E1 1 to E19. Less than 5\% of the SCG and DRG neurons were supported by either BDNF or NT-4/5 at both E 15 and E 18 , whereas the majority of these neurons were supported by NGF.

To determine whether BDNF and NT-4/5 act on the same subsets of trigeminal, jugular, and nodose ganglia neurons, cultures of these neurons were grown in the presence of saturating concentrations $(2 \mathrm{ng} / \mathrm{ml})$ of BDNF or NT- $4 / 5$ alone and with both neurotrophins. Cultures of E11 neurons containing individual factors or a combination of BDNF and NT $-4 / 5$ sustained the survival of a similar number of neurons for $48 \mathrm{hr}$ (data not shown). The lack of an additive effect indicates that BDNF and NT-4/5 promotc the survival of the same ncuronal populations.

To determine whether the early survival-promoting effects of BDNF and NT-4/5 on NGF-dependent cutaneous sensory neurons are exerted over the same period of development, we compared the ability of BDNF and NT-4/5 to prevent the death of cultured trigeminal neurons at ages ranging from E10 to E14. Figure 2 shows that age-related changes in the response of trigeminal neurons to NT-4/5 and BDNF are remarkably similar. E10 and E11 neurons were the most responsive. There was a fourfold decrease in the number of responding neurons between E11 and E12, and there was a further smaller decrease in responsiveness at later ages. This indicates that BDNF and NT$4 / 5$ are active on trigeminal neurons over the same period of development.

To investigate the relative potencies of BDNF and NT-4/5, trigeminal and nodose neurons were grown in the presence of different concentrations of BDNF or NT-4/5 and the number of surviving cells was determined $48 \mathrm{hr}$ later. BDNF and NT4/5 supported the survival of E10 and E11 trigeminal neurons to the same extent over a broad range of factor concentrations (Fig. $3 A, B$ ). Likewise, there was no significant difference in the dose responses of nodose neurons to BDNF and NT-4/5 in cultures set up at E12 (Fig. 3C), E15, and E18 (not shown). 


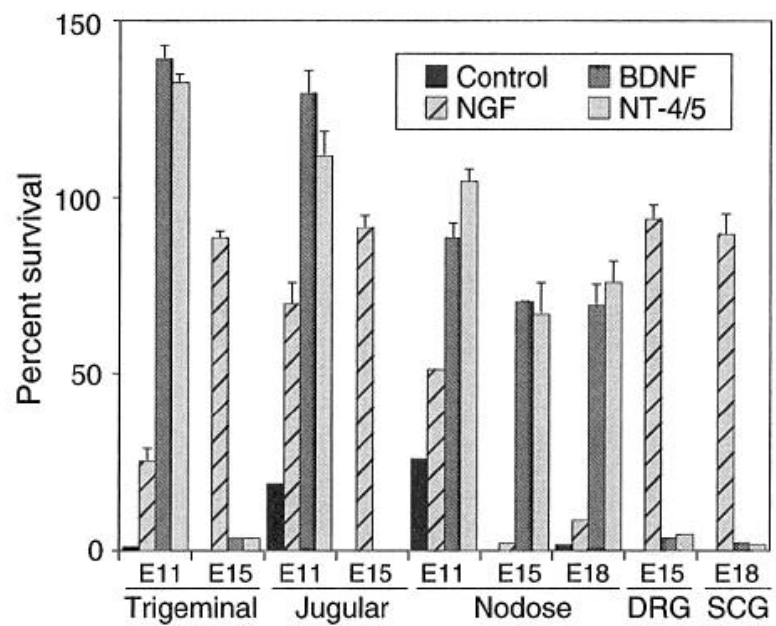

Figure 1. Survival of mouse embryo neurons in response to neurotrophins. The bar graph shows the percentage of neurons surviving after $48 \mathrm{hr}$ in low-density, dissociated cultures containing $2 \mathrm{ng} / \mathrm{ml}$ of NGF, BDNF, or NT-4/5. The mean + SEM of triplicate cultures are shown.

Cultures of sensory ganglia from early developmental stages often contain progenitor cells that proliferate and differentiate in vitro (Rohrer et al., 1985: Wright et al., 1992) and it is feasible that the increase in the number of neurons in E11 cultures following neurotrophin treatment resulted from enhanced proliferation or differentiation of progenitor cells and not from the survival of post-mitotic neurons. To exclude this possibility, cohorts of neurons were identified by their bipolar morphology $6 \mathrm{hr}$ after plating. BDNF or NT-4/5 was then added and the fate of the individual neurons was monitored for the next 42 hr. In these cohort experiments, $85 \pm 3.8 \%$ (mean \pm SEM, $n$ $=3$ ) of neurons grown with BDNF and $89.7 \pm 5.2 \%$ (mean \pm SEM, $n=3$ ) of neurons grown with NT-4/5 survived from 6 to $48 \mathrm{hr}$ in culture. In control cultures, none of the neurons identified at $6 \mathrm{hr}$ survived to $48 \mathrm{hr}$. This indicates that BDNF and NT-4/5 have a direct survival-promoting effect on early trigeminal neurons. The fact that early trigeminal and jugular neurons cultured with BDNF or NT- $4 / 5$ contained more neurons at $48 \mathrm{hr}$ than at $6 \mathrm{hr}$ after plating (Fig. 1) suggests that proliferation or differentiation of progenitor cells occurs in these cultures. It is therefore possible that, in addition to their survival-promoting effects, BDNF and NT-4/5 act as mitogens or differentiation accelerating factors for neuronal progenitors in these cultures. Finally, although we did not undertake a quantitative study of neuronal morphology, there was no obvious difference in cell body size and in neurite length and branching between neurons surviving with BDNF and neurons surviving in parallel cultures with NT-4/5.

\section{Effect of NT-4/5 on chick embryo neurons}

The specificity and the potency of NT-4/5 were also tested on cranial sensory and autonomic neurons from E10 chick embryos. At this developmental age, cranial chick embryo neurons can be dissected as homogeneous populations and can be separated from non-neuronal cells by differential sedimentation (Davies, 1986). Furthermore, these neurons have an absolute dependence on neurotrophins for survival, and without exogenously added factors will all die by $48 \mathrm{hr}$ (except for a very small percentage in SCG cultures). Surprisingly, NT-4/5 at a concentration that is above saturation for responsive embryonic

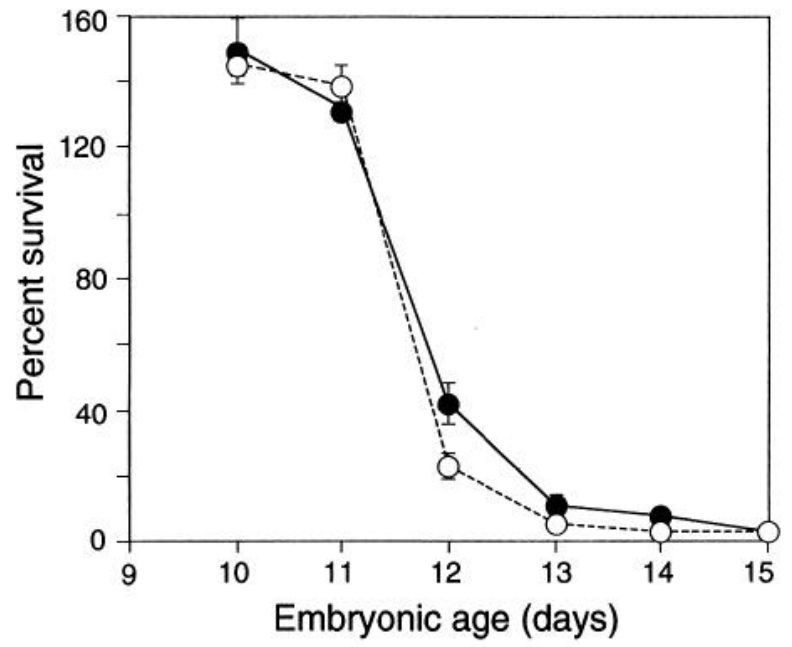

Figure 2. The survival of E10-E15 mouse trigeminal neurons in cultures containing BDNF or NT-4/5. The graph shows the number of neurons surviving after $48 \mathrm{hr}$ incubation with $2 \mathrm{ng} / \mathrm{ml}$ BDNF (open circles) or $2 \mathrm{ng} / \mathrm{ml} \mathrm{NT}-4 / 5$ (solid circles) expressed as a percentage of the number of neurons identified $6-9 \mathrm{hr}$ after plating. The mean \pm SEM of triplicate cultures from three separate experiments at each age are shown.

mouse neurons $(2 \mathrm{ng} / \mathrm{ml})$ had no effect on any embryonic chick cranial neurons. We therefore examined the efficacy of NT-4/5 at $50 \mathrm{ng} / \mathrm{ml}$. As shown in Figure 4, addition of NT-4/5 at this concentration had no or negligible effect on the survival of E10 BDNF-dependent TMN, DMTG, and nodose neurons, NGFdependent DMTG, jugular, and sympathetic neurons, and CNTF-dependent parasympathetic neurons. In the same experiments, the majority of neurons were supported by $2 \mathrm{ng} / \mathrm{ml}$ of the appropriate trophic factor. Furthermore, NT-4/5 did not prevent the death of these neuronal populations even at much higher concentrations (Fig. 5). In addition, cultures containing the most effective neurotrophic factor alone or in combination with NT-4/5 (at $50 \mathrm{ng} / \mathrm{ml}$ ) sustained the survival of a similar number of neurons (data not shown).

Although E10 chick neurons did not respond to NT-4/5, E6 DMTG neurons, which are BDNF-dependent at this age (BujBello, Pinon, and Davies, unpublished observations), did respond to $50 \mathrm{ng} / \mathrm{ml}$ of this factor. We therefore compared the response of these neurons to the two factors (Fig. 6). Although a similar number of neurons survived in the presence of saturating concentrations of either NT-4/5 or BDNF, NT-4/5 was far less potent. For BDNF, half-maximal survival was obtained at a concentration of $7 \mathrm{pg} / \mathrm{ml}$, while for NT-4/5, half-maximal survival was obtained at $8 \mathrm{ng} / \mathrm{ml}$, suggesting that NT-4/5 is 3 orders of magnitude less potent than BDNF as a survival factor for E6 DMTG neurons. Thus, unlike other neurotrophins, NT$4 / 5$ can discriminate between mouse and chick embryonic neurons. Furthermore, although all the BDNF-responsive neurons we tested in the mouse embryo are supported by NT-4/5, only subpopulations of BDNF-responsive neurons are supported by NT-4/5 in the chick embryo.

\section{Discussion}

We have quantitatively determined the ability of NT-4/5 to promote the survival of sensory and autonomic neurons of mouse and chick embryos in low-density, glia-free cultures. NT-4/5 promoted the survival of mouse E11 trigeminal and jugular 


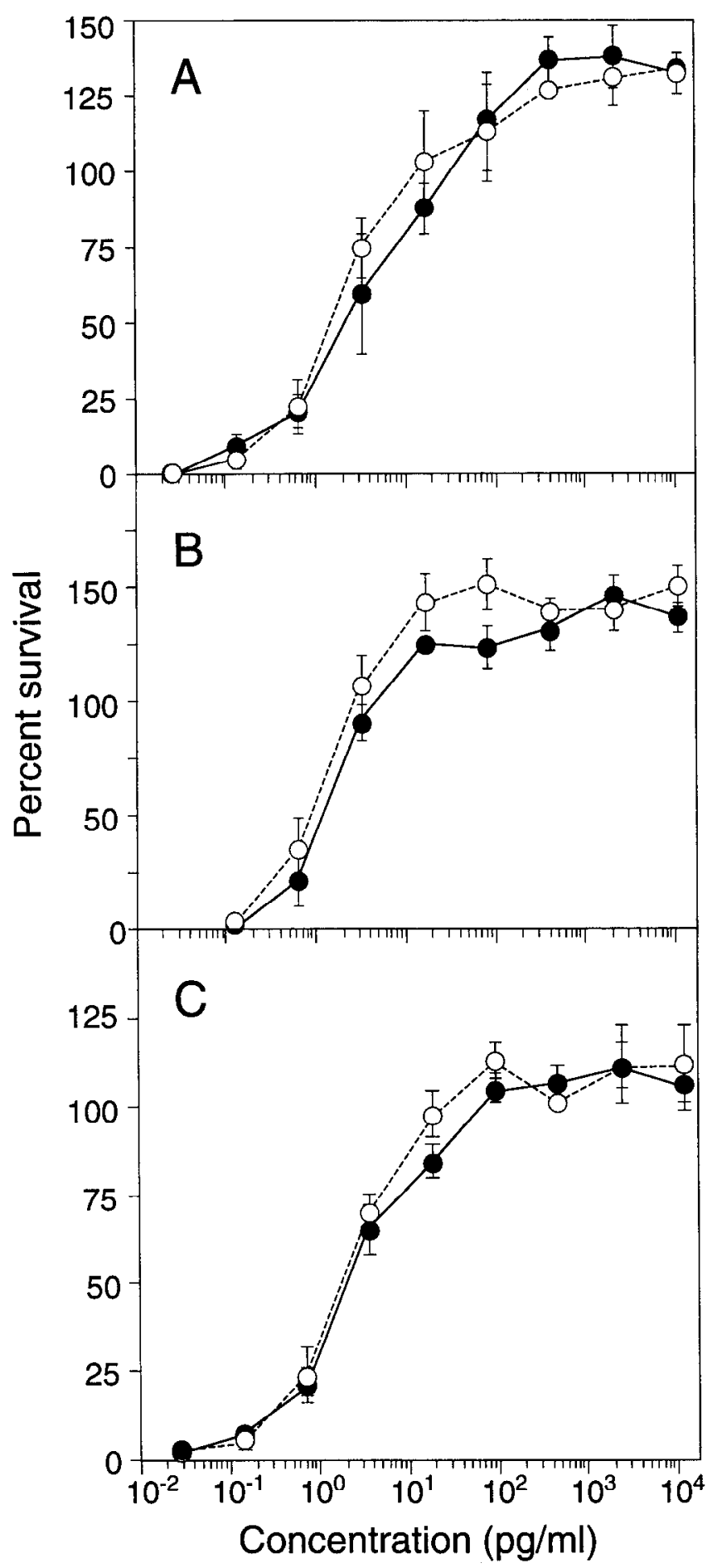

Figure 3. Dose responses of embryonic mouse trigeminal and nodose neurons to BDNF and NT-4/5: the percentage of E10 trigeminal neurons $(A)$, E11 trigeminal neurons $(B)$, and E12 nodose neurons $(C)$ surviving after $48 \mathrm{hr}$ incubation with different concentrations of BDNF (open circles) or NT-4/5 (solid circles). The number of neurons identified 6 $9 \mathrm{hr}$ and $48 \mathrm{hr}$ after plating was used to calculate the percentage. The mean \pm SEM of triplicate cultures from representative experiments are shown.

neurons, which are transiently dependent on BDNF at this developmental stage, and of mouse E11-E18 nodose neurons, which also depend on BDNF. NT-4/5, at the concentration tested, had negligible effect on the survival of mouse E15 and E18 DRG and SCG neurons, and E15 trigeminal and jugular neurons that

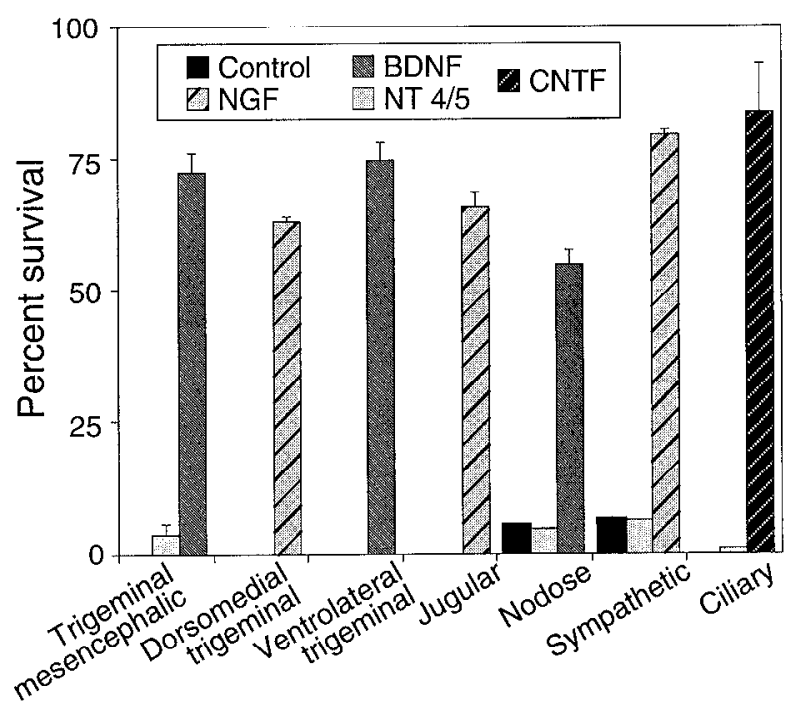

Figure 4. Survival of E10 chicken embryo neurons in response to neurotrophins. The bar graph shows the percentage of neurons surviving after $48 \mathrm{hr}$ in low-density, dissociated, glia-free cultures containing no neurotrophic factors (controls), $50 \mathrm{ng} / \mathrm{ml}$ of NT-4/5, or $2 \mathrm{ng} / \mathrm{ml}$ of the maximally effective neurotrophic factor for each population of neurons. The mean + SEM of triplicale cultures are shown.

are NGF-dependent at these embryonic stages. Surprisingly, although NT-4/5 and BDNF were equipotent in promoting the survival of mouse neurons, NT-4/5 was 3 orders of magnitude less potent than BDNF as a survival factor for homologous populations of chick embryo neurons. Furthermore, some BDNF-responsive chick neurons did not show any response to NT-4/5 at much higher concentrations. Thus, NT-4/5 appears to be a species-specific neurotrophin. It displays the same activities as BDNF on mammalian cranial neurons and can discriminate between different BDNF-responsive chick neurons.

One explanation for the specificity of NT-4/5 among vertebrates is that the structure of $\mathrm{N}^{\prime} \mathrm{I}^{\prime}-4 / 5$ was not as conserved between mammals and birds as that of other neurotrophins (Ip et al., 1992). Alternatively, it is possiblc that NT-4/5 fulfills requirements specific for the mammalian nervous system and is not present in birds. In addition, there may exist populations of neurons in the chick embryo that are very sensitive to human NT-4/5. Even if this were the case, we would have to conclude that there has not been selective pressure to maintain the same neuronal specificity of NT-4/5 in the avian and mammalian lineages.

Although NT-4/5 is a highly potent neurotrophin for certain populations of embryonic mouse neurons, its neuronal specificity is not unique. In our study of five different populations of neurons at stages throughout their early development, NT-4/5 displayed identical neuronal specificity and potency to BDNF. In contrast, the neuronal specificity of NGF and NT3, although partially overlapping with that of BDNF and NT-4/5 on early trigeminal and jugular neurons, was clearly different (Fig. 1; Hohn et al., 1990; Rosenthal et al., 1990; Buj-Bcllo, Pinon, and Davies, unpublished observations). The apparent redundancy in function of NT-4/5 observed here could be explained in several ways. First, NT-4/5 may possess unique activities on neuronal populations that have not been tested in this study. Second, although BDNF and NT-4/5 promote the survival of identical neuronal populations in culture, they may each have 


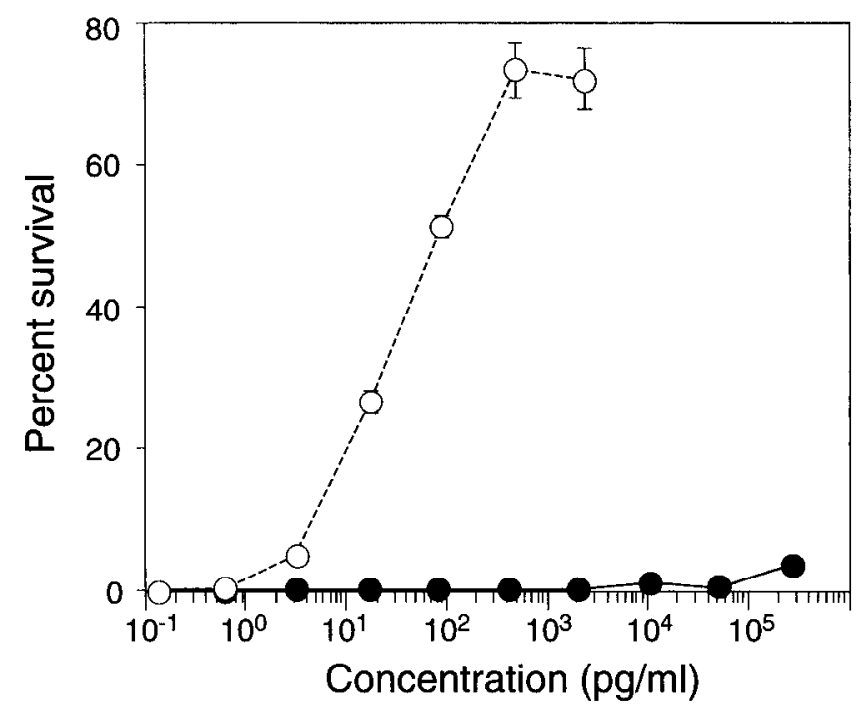

Figure 5. Dose-responses of embryonic chick TMN neurons to BDNF and NT-4/5. The number of E10 TMN neurons surviving after $48 \mathrm{hr}$ incubation with different concentrations of BDNF (open circles) or NT$4 / 5$ (solid circles) is expressed as a percentage of the number of neurons identified $6-9 \mathrm{hr}$ after plating. The mean \pm SEM of triplicate cultures from representative experiments are shown.

distinct activities in vivo resulting from modulation by accessory factors. Third, it is possible that the only difference between BDNF and NT $-4 / 5$ is their distinct tissue distribution. If correct, this possibility implies that amino acids that are not conserved between the two proteins are not essential for function.

The common neuronal specificity of BDNF and NT-4/5 in mouse embryos may be a consequence of the binding of these neurotrophins to the same cell surface receptor. Two classes of neurotrophin receptors have been identified: $\mathrm{p} 75$ and the trk family of tyrosine kinases of which three members, trkA, trkB, and trkC, have been identified (Chao, 1992; Meakin and Shooter, 1992). Considerable evidence suggests that trk receptors are directly involved in neurotrophin signal transduction and ligand discrimination. Neurotrophins promote rapid autophosphorylation of trk tyrosine kinases (Kaplan et al., 1991a,b; Klein et al., 1991 a,b; Soppet et al., 1991) and elicit responses in oocytes (Nebreda et al., 1991), cell lines (Cordon et al., 1991; Glass et al., 1991; Lamballe et al., 1991; Loeb et al., 1991; Squinto et al., 1991), and embryonic neurons (T. Allsopp, M. Robinson, S. Wyatt, and A. M. Davies, unpublished observations) transfected or microinjected with trk cDNAs. In contrast, p75 is probably not a functional neurotrophin receptor alone (Bothwell, 1991) and binds NGF, BDNF, NT-3, and Xenopus NT-4 with similar affinity (Sutter et al., 1979; Rodriguez-Tébar and Barde, 1988; Hallbook et al., 1991; Rodriguez-Tébar et al., 1992). Using proliferation (Ip et al., 1992) and tyrosine phosphorylation (Berkemeier et al., 1991; L. Berkemeier and A. Rosenthal, unpublished observations) assays in $3 \mathrm{~T} 3$ fibroblasts expressing either trkA or trkB, NT-4/5 was shown to be a potent activator of trkB and a weak activator of trkA. Like NT-4/5, BDNF also promotes rapid phosphorylation of trkB and elicits a mitogenic response in trkB-expressing fibroblasts (Glass et al., 1991; Klein et al., 1991b; Soppet et al., 1991; Squinto et al., 1991) but is inactive on trkA and trkC (Lamballe et al., 1991). Thus, it seems likely that BDNF and NT-4/5 exert their common effects on the survival embryonic mouse neurons by acting via trkB.

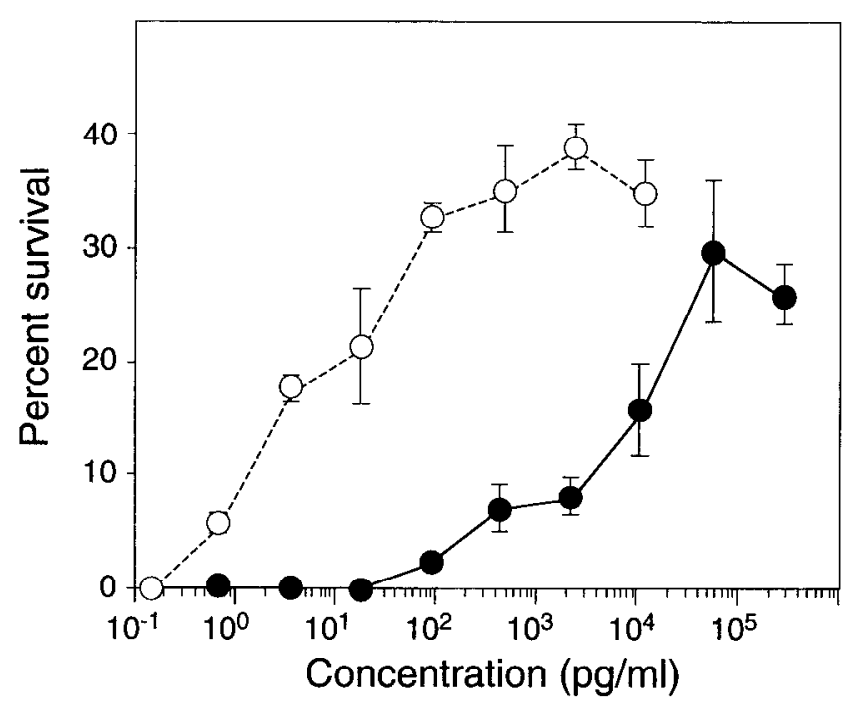

Figure 6. Dose-responses of embryonic chick DMTG neurons to BDNF and NT-4/5. The number of E6 DMTG neurons surviving after $48 \mathrm{hr}$ incubation with different concentrations of BDNF (open circles) or NT$4 / 5$ (solid circles) is expressed as a percentage of the number of neurons identified 6-9 $\mathrm{hr}$ after plating. The mean \pm SEM of triplicate cultures from representative experiments are shown.

$\mathrm{NT}-4 / 5$ at $50 \mathrm{ng} / \mathrm{ml}$ did not show any survival promoting effects on either E18 SCG neurons or E15 trigeminal neurons, both of which were supported by NGF. Therefore, although NT- $4 / 5$ at high concentrations can activate the trkA high-affinity NGF receptor (Hempstead et al., 1991; Kaplan et al., 1991a,b; Klein et al., 1991a; Lamballe et al., 1991; Meakin et al., 1992) in fibroblasts (Berkemeier et al., 1991; Ip et al., 1992; Berkemeier and Rosenthal, unpublished observations), this activation does not seem to have any physiological relevance for the survival of developing mouse neurons.

Previous studies of the biological activity of NT $-4 / 5$ reported that it promoted the survival of substantial numbers of embryonic chick DRG (Ip et al., 1992) and sympathetic (Berkemeier et al., 1991) neurons grown in dissociated culture. The discrepancy between these findings and our present results may have resulted from differences in the purity, processing, or concentration of NT-4/5 used. Earlier studies used partially purified conditioned media from mammalian cell lines that contained unknown concentration of NT-4/5 and could carry aggregated or truncated forms of this protein. In contrast, in the present study we used highly purified recombinant NT-4/5 at known concentrations that was produced in $E$. coli.

Although BDNF and NT-4/5 display identical specificity and potency as survival factors for mouse neurons, they differ in their ability to prevent the death of chick embryo neurons. NT$4 / 5$, at a concentration of $50 \mathrm{ng} / \mathrm{ml}$, promoted the survival of E6 DMTG neurons but was an ineffective survival factor for E10 TMN neurons. In contrast, BDNF displayed similar potency in promoting the survival of both of these neuronal populations and was more potent than NT-4/5. Thus, NT-4/5 and BDNF differ in both specificity and potency as survival factors for chick embryo neurons. Although E6 DMTG neurons respond to NGF (Buj-Bello, Pino, and Davies, unpublished observations) whereas E10 TMN neurons are unresponsive to NGF (Davies et al., 1987), it is unlikely that NT-4/5 exerts its effects on E6 DMTG neurons via a regular trkA receptor because it 
does not support the survival of other NGF-dependent neurons. Alternatively, it is possible that E6 DMTG and E10 TMN neurons express different forms of the $\operatorname{trk} A$ or $t r k B$ receptors or of p75-like accessory molecules. Multiple $t r k B$ transcripts and at least three distinct $t r k B$ receptors that differ in their cytoplasmic domains have already been identified (Klein et al., 1989, 1990; Middlemas et al., 1991). The ability of human NT-4/5 to discriminate between different $t r k B$-responsive chick neurons suggests another level of complexity in the interactions between neurotrophins and their receptors.

\section{References}

Barbin G, Manthorpe M, Varon S (1984) Purification of the chick eye ciliary neuronotrophic factor. J Neurochem 43:1468-1478.

Barde YA, Edgar D, Thoenen H (1982) Purification of a new neurotrophic factor from mammalian brain. EMBO J 1:549-553.

Barde YA, Davies AM, Johnson JE, Lindsay RM, Thoenen H (1987) Brain derived neurotrophic factor. Prog Brain Res 71:185-189.

Berkemeier LR, Winslow JW, Kaplan DR, Nikolics K, Goeddel DV, Rosenthal A (1991) Neurotrophin-5: a novel neurotrophic factor that activates Trk and TrkB. Neuron 7:857-866.

Bothwell M (1991) Keeping track of neurotrophin receptors. Cell 65: 915-918.

Buchman VL, Davies AM (1993) Different neurotrophins are expressed and act in a developmental sequence to promote the survival of embryonic sensory neurons. Development 118:989-1001.

Cattaneo E, McKay RDG (1990) Proliferation and differentiation of neuronal stem cells regulated by nerve growth factor. Nature 347 $762-765$.

Chao M (1992) Neurotrophin receptors: a window into neuronal differentiation. Cell 9:583-593.

Chun LL, Patterson PH (1977) Role of nerve growth factor in the development of rat sympathetic neurones in vitro. II. Developmental studies. J Cell Biol 75:705-711.

Cordon-Cardo C, Tapley P, Jing S, Nanduri V, O'Rourke E, Lamballe F, Kovary K, Klein R, Jones KR, Reichardt LF, Barbacid M (1991) The trk tyrosine protein kinase mediates the mitogenic properties of nerve growth factor and neurotrophin-3. Cell 66:173-183.

Davies AM (1986) The survival and growth of embryonic proprioceptive neurons is promoted by a factor present in skeletal muscle. Dev Biol 115:56-67.

Davies AM (1987) Molecular and cellular aspects of patterning sensory neurone connections in the vertebrate nervous system. Development 101:185-208.

Davies AM (1989) Neurotrophic factor bioassay using dissociated neurons. IBRO Hdbk 12:95-109.

Davies AM, Lindsay RM (1985) The cranial sensory ganglia in culture: differences in the response of placode-derived and neural crest-derived neurons to nerve growth factor. Dev Biol 111:62-72.

Davies AM, Lumsden AGS (1983) Influence of nerve growth factor on developing dorso-medial and vento-lateral neurons of chick and mouse trigeminal ganglia. Int J Dev Neurosci 1:171-177.

Davies AM, Thoenen H, Barde YA (1986a) Different factors from the central nervous system and periphery regulate the survival of sensory neurones. Nature 319:497-499.

Davies AM, Thoenen H, Barde YA (1986b) The response of chick sensory neurons to brain-derived neurotrophic factor. $J$ Neurosci 6:1897-1904.

Davies AM, Lumsden AG, Rohrer H (1987) Neural crest-derived proprioceptive neurons express nerve growth factor receptors but are not supported by nerve growth factor in culture. Neuroscience 20 : $37-46$

Ernfors P, Ibanez CF, Ebendal T, Olson L, Persson H (1990) Molecular cloning and neurotrophic activities of a protein with structural similarities to nerve growth factor: developmental and topographical expression in the brain. Proc Natl Acad Sci USA 87:5454-5458.

Glass DJ, Nye SH, Hantzopoulos P, Macchi MJ, Squinto SP, Goldfarb M, Yancopoulos GD (1991) TrkB mediates BDNF/NT-3-dependent survival and proliferation in fibroblasts lacking the low affinity NGF receptor. Cell 66:405-413.

Greene LA (1977) Quantitative in vitro studies on the nerve growth factor (NGF) requirement of neurons. I. Sympathetic neurons. Devel Biol 58:96-105.

Hallbook F, Ibanez CF, Persson H (1991) Evolutionary studies of the nerve growth factor family revealed a novel member abundantly expressed in Xenopus ovary. Neuron 6:845-858.

Hatanaka H, Tsukui H, Nihonmatsu I (1988) Developmental change in the nerve growth factor action from induction of choline acetyltransferase to promotion of cell survival in cultured basal forebrain cholinergic neurons from postnatal rats. Brain Res 467:85-95.

Hempstead BL, Martin ZD, Kaplan DR, Parada LF, Chao MV (1991) High-affinity NGF binding requires coexpression of the trk protooncogene and the low-affinity NGF receptor. Nature 350:678-683.

Henderson CE, Camu W, Mettling C, Govin A, Poulsen K, Karihaloo M, Rullamas J, Evans T, McMahon SB, Armanini MP, et al. (1993) Neurotrophins promote motor neuron survival and are present in embryonic limb bud. Nature 363:266-270.

Hofer MM, Barde YA (1988) Brain-derived neurotrophic factor prevents neuronal death in vivo. Nature 331:261-262.

Hohn A, Leibrock J, Bailey K, Barde YA (1990) Identification and characterization of a novel member of the nerve growth factor/brainderived neurotrophic factor family. Nature 344:339-341.

Hyman C, Hofer M, Barde YA, Juhasz M, Yancopoulos GD, Squinto SP, Lindsay RM (1991) BDNF is a neurotrophic factor for dopaminergic neurons of the substantia nigra. Nature 350:230-232.

Ip NY, Ibanez CF, Nye SH, McClain J, Jones PF, Gies DR, Belluscio L, Le Beau MM, Espinosa R III, Squinto SP, Persson H, Yancopoulos GD (1992) Mammalian neurotrophin-4: structure, chromosomal localization, tissue distribution, and receptor specificity. Proc Natl Acad Sci USA 89:3060-3064.

Johnson EJ, Gorin PD, Osborne PA, Rydel RE, Pearson J (1982) Effects of autoimmune NGF deprivation in the adult rabbit and offspring. Brain Res 240:131-140.

Johnson EJ, Barde YA, Schwa M, Thoenen H (1986) Brain-derived neurotrophic factor supports the survival of cultured rat retinal ganglion cells. J Neurosci 6:3031-3038.

Jones KR, Reichardt LF (1990) Molecular cloning of a human gene that is a member of the nerve growth factor family. Proc Natl Acad Sci USA 87:8060-8064.

Kalcheim C, Barde YA, Thoenen H, Le DN (1987) In vivo effect of brain-derived neurotrophic factor on the survival of developing dorsal root ganglion cells. EMBO J 6:2871-2873.

Kalcheim C, Carmeli C, Rosenthal A (1992) Neurotrophin-3 is a mitogen for cultured neural crest cells. Proc Natl Acad Sci USA 89: 1661-1665.

Kaplan DR, Hempstead BL, Martin ZD, Chao MV, Parada LF (1991a) The trk proto-oncogene product: a signal transducing receptor for nerve growth factor. Science 252:554-558.

Kaplan DR, Martin ZD, Parada LF (1991b) Tyrosine phosphorylation and tyrosine kinase activity of the $t r k$ proto-oncogene product induced by NGF. Nature 350:158-160.

Klein R, Parada LF, Coulier F, Barbacid M (1989) TrkB, a novel tyrosine protein kinase receptor expressed during mouse neural development. EMBO J 8:3701-3709.

Klein R, Conway D, Parada LF, Barbacid M (1980) The trk $R$ tyrosine protein kinase gene codes for a second neurogenic receptor that lacks the catalytic kinase domain. Cell 61:647-656.

Klcin R, Jing SQ, Nanduri V, O'Rourke E, Barbacid M (1991a) The trk proto-oncogene encodes a receptor for nerve growth factor. Cell 65:189-197.

Klein R, Nanduri V, Jing SA, Lamballe F, Tapley P, Bryant S, Cordon CC, Jones KR, Reichardt LF, Barbacid M (1991b) The TrkB tyrosine protein kinase is a receptor for brain-derived neurotrophic factor and neurotrophin-3. Cell 66:395-403.

Lamballe F, Klein R, Barbacid M (1991) TrkC, a new member of the Trk family of tyrosine protein kinases, is a receptor for neurotrophin3. Cell 66:967-979.

Leibrock J, Lottspeich F, Hohn A, Hofer M, Hengerer B, Masiakowski P, Thoenen H, Barde YA (1989) Molecular cloning and expression of brain-derived neurotrophic factor. Nature 341:149-152.

Levi-Montalcini R, Aloe L (1985) Differentiating effects of murine nerve growth factor in the peripheral and central nervous system of Xenopus laevis tadpoles. Proc Natl Acad Sci USA 82:7111-7115.

Levi-Montalcini R, Angeletti P (1968) Nerve growth factor. Physiol Rev 48:534-569.

Lindsay RM, Rohrer H (1985) Placodal sensory neurons in culture: nodose ganglion neurons are unresponsive to NGF, lack NGF receptors but are supported by a liver-derived neurotrophic factor. Dev Biol 112:30-48.

Lindsay RM, Thoenen H, Barde YA (1985) Placode and neural crest- 
derived sensory neurons are responsive at early developmental stages to brain-derived neurotrophic factor. Dev Biol 112:319-328.

Loeb DM, Maragos J, Martin ZD, Chao MV, Parada LF, Greene LA (1991) The trk proto-oncogene rescues NGF responsiveness in mutant NGF-nonresponsive PCl 2 cell lines. Cell 66:961-966.

Maisonpierre PC, Belluscio L, Squinto S, Ip NY, Furth ME, Lindsay RM, Yancopoulos GD (1990) Neurotrophin-3: a ncurotrophic factor related to NGF and BDNF. Science 247:1446-1451.

Meakin SO, Shooter EM (1992) The nerve growth factor family of receptors. Trends Neurosci 15:323-331.

Meakin SO, Suter U, Drinkwater CC, Welcher AA, Shooter EM (1992) The rat $t r k$ protooncogene product exhibits properties characteristic of the slow nerve growth factor receptor. Proc Natl Acad Sci USA 89:2374-2378.

Middlemas DS, Lindberg RA, Hunter T (1991) TrkB, a neural receptor protein-tyrosine kinase: evidence for a full-length and two truncated receptors. Mol Cell Biol 11:143-153.

Nebreda AR, Martin ZD, Kaplan DR, Parada LF, Santos E (1991) Induction by NGF of meiotic maturation of Xenopus oocytes expressing the $t r k$ proto-oncogene product. Science 252:558-561.

Oppenheim WR, Wei QY, Prevette D, Yan Q (1992) Brain-derived neurotrophic factor rescues developing avian motoneurons from cell death. Nature 360:755-757.

Rodriguez-Tébar A, Barde Y (1988) Binding characteristics of brainderived neurotrophic factor to its receptors on neurons from the chick embryo. J Neurosci 8:3337-3342.

Rodriguez-Tébar A, Dechant G, Gotz R, Barde YA (1992) Binding of neurotrophin- 3 to its neuronal receptors and interactions with nerve growth factor and brain-derived neurotrophic factor. EMBO J 11: 917-922.

Rohrer H, Henke FS, El ST, Lux HD, Thoenen H (1985) Progenitor cells from embryonic chick dorsal root ganglia differentiate in vitro to neurons: biochemical and electrophysiological evidence. EMBO J 4:1709-1714.

Rosenthal A, Goeddel DV, Nguyen T, Lewis M, Shih A, Laramcc GR, Nikolics K, Winslow JW (1990) Primary structure and biological activity of a novel human neurotrophic factor. Neuron 4:767-773.
Rosenthal A, Goeddel DV, Nguyen T, Martin E, Burton LE, Shih A, Laramee GR, Wurm F, Mason A, Nikolics K, et al. (1991) Primary structure and biological activity of human brain-derived neurotrophic factor. Endocrinology 129:1289-1294.

Sendtner M, Holtmann B, Kolbeck R, Thornen H, Barde AY (1992) Brain-derived neurotrophic factor prevents the death of motoneurons in newborn rats after nerve section. Nature 360:755-757.

Sieber BM (1991) Role of the neurotrophic factors BDNF and NGF in the commitment of pluripotent neural crest cells. Neuron 6:949955.

Soppet D, Escandon E, Maragos J, Middlemas DS, Reid SW, Blair J, Burton LE, Stanton BR, Kaplan DR, Hunter T, et al. (1991) The neurotrophic factors brain-derived neurotrophic factor and neurotrophin-3 are ligands for the TrkB tyrosine kinase receptor. Cell 65:895-903.

Squinto SP, Stitt TN, Aldrich TH, Davis S, Bianco SM, Radziejewski C, Glass DJ, Masiakowski P, Furth ME, Valenzuela DM, DiStefano PS, Yancopoulos GD (1991) trkB encodes a functional receptor for brain-derived neurotrophic factor and neurotrophin-3 but not nerve growth factor. Cell 65:885-893.

Sutter A, Riopcllc RJ, Harris-Warrick RM, Shooter EM (1979) Nerve growth factor receptors. Characterization of two distinct classes of binding sites on chick embryo sensory ganglia. J Biol Chem 254: 5972-5982.

Theiler K (1972) The house mouse (development and normal stages from fertilization to 4 weeks). Berlin: Springer.

Thoenen H, Barde Y (1980) Physiology of nerve growth factor. Physiol Rev 60:1284-1335.

Wright E, Vogel KS, Davies AM (1992) Neurotrophic factors promote the maturation of developing sensory neurons before they become dependent on these factors for survival. Neuron 9:139-150.

Yan Q, Elliott J, Snider DW (1992) Brain-derived neurotrophic factor rescues spinal motoneurons axotomy-induced cell death. Nature 360: 755-757. 